\title{
Sürücü Eğitiminde İnformal Öğrenmenin Rolü: Türkiye Örneği
}

\author{
Role of Informal Learning in Driving Education: Turkey Case
}

\begin{abstract}
Kahan INAL ${ }^{*}$
Öz: Türkiye’de sürücü eğitimini yetişkin eğitimi bağlamında ele alan ve informal öğrenmenin sürücülük eğitimindeki önemini ortaya koymayı amaçlayan bu çalışma, nitel bir araştırmadır. Türkiye'deki sürücü kurslarında gerçekleşen eğitim ve sürücülüğü öğrenme kısımlarıyla ilgili veriler görüşme yoluyla toplanmıştır. Görüşmeler; yapılan sınavlar sonucunda sürücü belgesi almaya hak kazanmış durumda olan sürücü adaylarıyla 2010 yılında Ankara İli’nde gerçekleştirilmiştir. Elde edilen verilerin analizinde betimsel analiz tekniğinden yararlanılmıştır. Araştırmada elde edilen bulgular, Türkiye'de özel MTSK'da sürücü eğitimi alan adayların çoğunluğunun sürücülüğü kurs dışında öğrendiklerini ortaya koymaktadır. Bulgulardan sürücü adaylarının büyük çoğunluğunun, kursa başlamadan önce veya kursla eşzamanlı olarak, sürücülüğü öğrenmek için kurs dışında informal öğrenme çalışmaları yaptıkları anlaşılmaktadır. Görüşme yapılan sürücü adayları öz-yönelimli birer öğrenen olarak sorumluluk alıp sürücülüğü öğrenme konusunda yürüttükleri çalışmalar sonucu gerçekleşen öğrenmeleri kurstaki çalışmalarına eklemlemişlerdir. $\mathrm{Bu}$ araştırma yetişkin birer öğrenen olan sürücü adaylarının hazır bulunuşlukları ve toplumsal rolleri çerçevesinde kendi öğrenme ihtiyaçları konusunda karar verme noktasında sorumluluk alarak hareket ettiklerini ortaya koymaktadır.
\end{abstract}

Anahtar sözcükler: Trafik, Eğitim, Yetişkin, İnformal Öğrenme

Abstract: This work, handling driving education in Turkey in terms of adult education and aimed to expose the importance of informal learning in driving education, is a qualitative research. Data on education in driving courses in Turkey and related to learning driving was collected through interviews. These interviews were conducted in 2010 in Ankara with student drivers who have the right to obtain their driving licenses after taking the tests. Descriptive analysis was applied to analyze the data obtained. The findings indicate that most of the student drivers, attending motor vehicle driving courses in Turkey, are learning driving outside of the courses. It was understood the most of the students in some way practice informal learning activities to learn driving before or during the course. As self-directing learners, the interviewees added what they learned during their practice to the studies they made during the course. This work reveals that student drivers, as adult learners, can act by taking responsibility for their own decisions about their learning needs, in terms of both their readiness and social roles.

Keywords: Traffic, Education, Adult, Informal Learning

\section{Giriş}

Günümüz dünyasında yaşanan bireysel ve toplumsal sorunlar içinde en önemlilerinden birisi de trafik sorunudur. Trafik, 2918 Sayılı Karayolları Trafik Kanunu’nun 3. maddesinde; “Yayaların, hayvanların ve araçların karayolları üzerindeki hal ve hareketleri” olarak tanımlanmıştır.

\footnotetext{
* PhD., Ankara Üniversitesi,Yaşamboyu Öğrenme ve Yetişkin Eğitimi ABD., Ankara, kahaninal@hotmail.com
} 
Trafik, her biri kendi içinde ve kendine ait pek çok dinamiğe sahip olan üç temel sistemden oluşur: çevre, araç ve insan. Bu üç sistem belli bir denge içinde olup, çeşitli faktörler ayrı ayrı ya da bütün olarak bu dengeyi bozabilir. Trafik sistemini oluşturan bu yapılardan herhangi birinde ortaya çıkacak bir aksaklık tüm sistemi olumsuz etkileyebilmektedir. Bu nedenle güvenli ve etkili bir trafik için, trafik sistemini oluşturan faktörlerin ideal koşulları taşıması gerekmektedir.

İnsanlar; yaya, yolcu, sürücü olarak çeşitli şekillerde trafik içinde yer alırlar. Emniyet Genel Müdürlüğ̈̈'nce, kaza yerinde doldurulan trafik kaza tespit tutanaklarının değerlendirilmesi sonucu hazırlanan ve her yıl yayınlanan Trafik İstatistik Yıllıkları, trafik kazalarının büyük çoğunluğunun insan hatası, kusuru ve ihmalinden kaynaklandığını göstermektedir. Bu durum trafik kazalarının azaltılması, düzenli ve güvenli bir trafik ortamının sağlanması için insan faktörünün, yol ve trafik güvenliği konusunda ağırlıklı olarak eğitilmesinin kaçınılmaz bir gereklilik olduğunu göstermektedir. Varış’a $(1998,1)$ göre, eğitim, bireylere bilgi ve beceri kazandırmanın ötesinde, toplumun yaşamasını ve kalkınmasını devam ettirebilecek ölçüde ve nitelikte değer üretmek, mevcut değerlerin dağılmasını önlemek, yeni ve eski değerleri bağdaştırmak sorumluluğu taşımaktadır. Dolayısıyla, toplumsal yaşamın ve ekonomik gelişmenin vazgeçilmez parçası olan ulaşımı daha güvenli hale getirmenin yolu toplumu oluşturan bireylere ulaşım sistemleri konusunda yeterli eğitimi vermekten geçmektedir.

\subsection{Araştırmanın Amacı}

Sürüş, çeşitli bilişsel, fiziksel, duyuşsal ve psikomotor becerilerin eşzamanlı yürütülmesini gerektiren karmaşık bir iştir (Young, \& Regan, 2007, 379). Bu karmaşık işin gerektirdiği becerilerin kazanılması uygun eğitim faaliyetleriyle mümkün olabilmektedir. Karayolu güvenliği eğitimi daha güvenli, daha yetkin sürücülerin varlığını sağlayan bir süreçtir. Sürücülüğg̈ öğrenenlerin güvenli sürüş tekniklerini geliştirmesi ve daha deneyimli sürücülük için güvenli sürüş becerilerini yenilemesi için kurslar vardır (DTMR, 2013).

Sürücü belgesi almak yetişkinlere özgü bir haktır. Belli bir yaşa gelince insanın doğruyu ve yanlışı, iyiyi ve kötüyü kendi başına ayırt edebileceğini varsayan "yasal" tanıma göre birey yürürlükte olan yasalarca oy kullanabilme, sürücü belgesi alabilme hakkına sahip olduğunda yetişkin kabul edilir. Kronolojik tanıma göre ise genel olarak 20'li yaşlar ve sonrası yetişkinlik olarak kabul edilebilir (Miser, 1999, 20).

$\mathrm{Bu}$ araştırmanın amacı Türkiye'de trafik güvenliği eğitiminin önemli bir alanı olan ve mevzuatta yerini bulan sürücü eğitim sistemi ile yetişkin birer birey olan sürücü adaylarının sürücülüğü informal olarak öğrenmesi arasındaki bağın incelenmesidir.

\subsection{Yetişkin Eğitimi}

Eğitim, yaşam boyu süren yani okul öncesinde ve okul yaşamında olduğu gibi okul sonrasında da devam eden dinamik bir süreçtir (Varış, 1998, 6-7). 21. yüzyılda yaşanan gelişmeler işçi, öğrenci, ebeveyn ya da vatandaş gibi rolü ne olursa tüm yetişkinlerin, eğitimsel seviyelerini geliştirmeleri ve temel becerilere sahip olmaları gerekliliğini ortaya çıkarmıştır. İş dünyası başta olmak üzere toplumun her katmanının değişime uğradığı bir dünya düzeninde, yetişkinlere kendilerini geliştirmek ve yenilemek için ihtiyaç duydukları eğitimin sağlanması giderek önemli bir konu haline gelmektedir (Drago-Severson, 2004, 4-5).

Hillier $(2005,76)$, insanların nasıl öğrendiğini etkileyebilecek çok sayıda faktörün varlığından söz ederken bu faktörler arasında; bireyin yetenekleri, motivasyonları, kişilik özellikleri, tutumları, daha önceki öğrenme deneyimleri, yaşam deneyimleri, sağlık durumları ve öğrenmeye ayrılan zamanla birlikte yaş faktörünü de saymaktadır. 
Görüldüğü üzere, yetişkin öğrenmesi yanıltıcı şekilde kolay bir durum gibi görünse de, oldukça karışık bir süreçtir. Çünkü öğrenme denilen konu, günlük yaşamda karşılaşılan şeylerin bilgide, yeteneklerde, değerlerde bir farklılık yaratması olarak tanımlanabilirken, yetişkin öğrenmesinin tam olarak ne olduğunu açıklamak, yetişkinlerin neden, nasıl ve ne zaman öğrendiklerini anlamak oldukça zordur. Bu nedenle tek bir tanım ya da açıklayıcı bir teori ileri sürülememekte, yetişkin öğrenimi pek çok teorinin oluşturduğu mozaiklerle, modellerle, kurallar listesiyle anlaşılmaya çalışılmaktadır (Merriam, 2011, 29).

Knowles'e göre, yetişkinler öğrenmeye başlamadan önce neden öğrenmeye gereksinim duyduklarını bilmelidirler, bağımlı benlik algısından öz-yönelimli olmaya doğru ilerlemesi gereklidir. Çocuklardan daha fazla deneyim birikimine sahiptirler ve bu birikimler farklı nitelikler taşımaktadır; dolayısıyla öğrenmeye hazır bulunuşlukları da var olan toplumsal rolleri ve yaşam evreleriyle ilişkili görevlerle bağlantılıdır. Yetişkinler, konu merkezli öğrenme yerine sorun merkezli öğrenmeye yatkındırlar ve dışsal güdülemeden çok içsel güdülenmeyle hareket ederler (akt: Tusting, \& Barton, 2011, 45).

Rogers’a (2007, 18-19) göre, motive edilmemiş bir kişi, öğrenmeyecek ve öğrenemeyecektir. Eğitimci grubunun motivasyonunu sürekli tazelemeli ve bu motivasyondan istifade etmelidir. Aksi takdirde öğrenmeye dönük tüm süreç çökecektir. Öğrenmenin gerçekleşebilmesi için yetişkin birey motive edilmelidir. Bu süreçte öğretmenin rolü ise motivasyonu ortaya çıkarmak ve bunu sürdürmektir.

Knowles ve Maslow gibi Rogers'ın modeli de kişisel gelişiminin insancıl kuramlarına dayanır. İnsanc1l psikolojide, kişinin gelişme potansiyeli ve isteği temel varsayım olarak kabul edilir; kişilerin kendilerini geliştirmek ve gerçekleştirmek için sınırsız bir potansiyeli olduğu vurgulanır. Bireylerde büyüme ve özyönelime yönelik içsel dürtüler olduğunu varsayan Rogers öğrenmeyi, öğrenen tarafindan başlatılan bir süreç olarak görür ve öğretmen (eğer varsa) bu süreçte yalnızca bir kolaylaştırıcı olarak hareket eder. Öğretmenin temel rolü, öğrenmenin mümkün olabilmesi için öğrenenlerin kendilerini keşfetmelerini sağlayacak ve diğerleriyle etkileşim kurmalarını destekleyecek güvenli bir ortam yaratmaktır (Tusting, \& Barton, 2011, 46-47).

\section{3. İnformal Öğrenme}

Blacker'a $(2005,85)$ göre, bireyler aslında tüm yaşamları boyunca birer öğrencidir. Bu süreçte yani yaşamı boyunca her gün edinilen tecrübeler çok değerlidir. Çünkü, bireyin yaşamı öğrenmeyle çevrilidir. Bireyin içinde yaşadığı dünya ve kendisiyle ilgili öğrendiklerinden kaynaklanan deneyimler; kim olduğunu, nasıl düşünüp hissettiğini ve nasıl hareket ettiğini günden güne şekillendirmesine yardım eder.

Bazı öğrenmeler üniversiteler, eğitim merkezleri, farklı isimlerdeki okullarda gerçekleşir ve bu tür öğrenmeye formal öğrenme denir. Bazı öğrenmeler ise gelişigüzel bir şekilde internette gezinirken, televizyon seyrederken, ilgi duyulan farklı gruplarda bulunurken gerçekleşir. Bu tür öğrenmeye ise informal öğrenme denir (Hillier, 2005, 27). Formal öğrenmede öğrenme kastı ile hareket edilip yapılandırılmış ve denetlenen bir süreç takip edilirken, informal öğrenmede yapılandırılmış içerik, denetlenen bir süreç ve öğrenme kastı ile hareket eden öğrenenlerden söz edilemez. İnformal öğrenme konusundaki çalışmaların, öğrenmenin derslik ve öğrenme ortamı dışında da oluşabileceğinin farkına varılmasının gereğine işaret ettiği; bu nedenle informal öğrenmeyi ve etkilerini yok saymak yerine, onun da değerli bir öğrenme biçimi olduğunu kabul etmenin çok önemli bir adım olacağını söylemek olanaklıdır.

İnformal öğrenmeyi formal öğrenmeden veya formal öğrenmeyi informal öğrenmeden üstün tutmak doğru görülmemektedir çünkü her ikisinin eğitimdeki yeri farklıdır ve biribirlerinin yerine 
geçemezler. Her iki öğrenme yöntemi de başarıya giden yolda oldukça önemlidir (Werquin, 2010, 8) ve informal öğrenme formal öğrenmeyi destekleyen bir öğrenme olabilir (Cross, 2007, 16).

Tusting ve Barton (2011, 58-60) informal öğrenme kavramının, yetişkinlerin neden örgün eğitim dışında da öğrendiklerini açıklamak için, planlanmamış ya da yapılandırılmamış öğrenmeyi adlandırmak için, toplumda örgün öğrenme kurumlarına karşı eğitim sunumlarını tanımlamak ya da akredite olmayan herhangi bir eğitim olanağını tanımlamak için kullanılabileceğini ifade etmişlerdir.

İnsanlar bir kafeteryada okulda öğrendiklerinden daha fazla şeyler öğrenebilirler. İnsanlar işlerini nasıl yapacaklarını iş ortamlarında beraber çalıştıkları arkadaşlarını gözlemleyerek, hata yaparak, çalışma arkadaşlarıyla konuşarak vb. yani doğal yöntemlerle bir başka anlatımla ayrıca bir eğitim programına katılmadan (training program) informal yollarla öğrenebilirler (Cross, 2007, XIX).

Yaşamın her alanında olduğu gibi karayolu güvenliği eğitiminin de informal bir boyutu bulunmaktadır. Bu bağlamda formal ve non formal eğitim faaliyetleri ile kampanyalar gibi informal eğitim programları ve yasal denetimler yol kullanıcılarına yönelik çalışmalar arasında sayılmaktadır. İnformal trafik güvenliği eğitiminin formal ve non formal eğitimden farkı belirli bir zaman çizelgesi ile sınırlı olmayışıdır (Venter, 2010). Karayolu trafik güvenliğini ilgilendiren eğitimler, yol kullanıcısı olan insan unsurunun karayolundaki konumuna (sürücü, yaya, yolcu) ve yaş gruplarına göre farklılıklar göstermektedir.

Davis ve Quimby $(2003,1)$ ise, yol güvenliği eğitiminin okullarda formal eğitim sisteminde ortak programda yer almakta olduğunu ifade ederek; herhangi bir nedenle eğitime katılmayan ve okuldan ayrılanlar gibi formal eğitimin dışındaki yetişkin ve çocuklara yönelik informal toplum destekli eğitimin sağlanmasının da önemli bir hak olduğunu belirtmişlerdir.

\section{Yöntem}

Türkiye'de karayolu trafik güvenliği eğitimini değerlendirmeyi amaçlayan bu araştırma nitel bir araştırmadır. Nitel araştırmada insanların kendilerinin ve diğerleriyle olan ilişkilerinin incelenmesini sağlayan ve daha çok karş1lklı etkileşim gerektiren görüşme, gözlem, odak grubu görüşmesi ve içerik inceleme gibi stratejiler kullanılmaktadır (Böke, et alii, 2009, 290).

\subsection{Verileri Toplama Aracı}

Araştırmanın Türkiye'deki sürücü eğitiminin etkililiği ve verimliliğiyle ilgili kısmında yöntem olarak, sosyal bilimler alanında yapılan pek çok çalışmada olduğu gibi görüşme, veri toplama yöntemi olarak seçilmiştir. Bu seçimde görüşme yönteminin; bireylerin deneyimlerine, tutumlarına, görüşlerine, şikayetlerine, duygularına ve inançlarına ilişkin bilgi elde etmede oldukça etkili bir yöntem olması etkili olmuştur (Yıldırım, \& Şimşek, 2003, 92). Görüşme tekniği, araştırmalarda veri toplama amacıyla yaygın olarak kullanılan eski ve köklü bir yaklaşımdır (Aziz, 1990, 73; Erdoğan, 2003, 190; Böke, et alii, 2009, 291; Karasar, 2011, 166).

\subsection{Verilerin Toplanması ve Analizi}

Görüşme formu oluşturulurken görüşülecek bireyin sürücü eğitim sisteminin neresinde olduğu ortaya konulmuş, araştırmanın amaçları doğrultusunda sorular hazırlanmış ve ön görüşmeler yapılmıştır. Soruların anlaşılırlığ , cevaplar ve eksiklikler tespit edilerek görüşme formlarına son şekli verilmiştir. Görüşmeler Ankara İli’nde 2010 yılında gerçekleştirilmiştir.

Bu kapsamda araştırmanın amaçları doğrultusunda; Ankara İli’nde sürücü belgesi almaya hak kazanmış sürücü adayları (n:30) ile görüşmeler gerçekleştirilmiştir. 
$\mathrm{Bu}$ araştırmada verilerin analizinde betimsel analiz tekniğinden yararlanılmıştır. Betimsel analiz yönteminde veriler görüşülenden elde edildiği şekilde değiştirilmeden alıntılar şeklinde okuyucuya aktarılır. Farklı kişilerin aynı konu hakkındaki benzer ve farklı düşüncelerinin görüşülenlerden elde edildiği tarzda aktarılması esastır. Bu yöntemde basit betimsel analizler yap1labilir (Böke, et alii, 2009, 313). Betimsel istatistik genelde çok sayıda birimden elde edilen verileri özetlemeyi, verileri niteliklerine göre ayırmayı amaçlar. Bu bağlamda kategorik veriler frekans dağılımı ile özetlenebilir (Balcı, 2006, 194).

Görüşmelerden elde edilen verilerin analizinde görüşmelerde bireylere yöneltilen sorular ana temalar olarak kullanılmış, görüşmelerde alınan cevapların incelenmesi ile saptanan boyutlar ise alt temalar olarak kullanılmıştır. İçerik analizinde her alt temanın tekrarlanma sıklığına bakılarak bu veriler sayısallaştırılmış ve tablolarda frekans ve yüzde olarak ifade edilmiştir. Görüşmelerle ilgili betimsel analizlerde alt temalara ilişkin "tipik" ifadeler görüşmelerden elde edildiği tarzda aktarılmıştır.

\section{Bulgular}

Sürücü adaylarının (SA) sürücü eğitim programına yönelik görüşlerini öğrenmek için sürücü belgesi almaya hak kazanmış sürücü adaylarıyla görüşülmüştür (n:30). Görüşülen sürücü adaylarının cinsiyetlerine göre dağılımı Tablo 1'de gösterilmektedir.

Tablo 1. Görüşülen Sürücü Adaylarının Cinsiyetlerine Göre Dağılımı (n:30)

\begin{tabular}{|c|c|c|}
\hline Cinsiyet & Sayı & \% \\
\hline Kadın & 9 & 30.0 \\
\hline Erkek & 21 & 70.0 \\
\hline Toplam & 30 & 100.0 \\
\hline
\end{tabular}

Görüldüğü üzere görüşülen sürücü adaylarının \%30’u kadın, \%70’i erkektir. İŞKUR (2013) verilerine göre 2002 yılında yüzde 14.6 olan sürücü belgesine sahip kadın oranı, 2011 yılında yüzde 19.9' a ulaşmıştır. Bu veriler kadın sürücü sayısının giderek arttığını göstermektedir.

Görüşülen sürücü adaylarının yazılı sınavdaki başarılarına göre dağılımı Tablo 2'de gösterilmektedir.

Tablo 2. Görüşülen Sürücü Adaylarının Yazılı Sınavdaki Başarılarına Göre Dağılımı (n:30)

\begin{tabular}{|c|c|c|c|c|}
\hline Cinsiyet & \multicolumn{2}{|c|}{$\begin{array}{c}\text { Yazılı Sınavı İk Hakkında Geçenlerin } \\
\text { Sayısı \% }\end{array}$} & \multicolumn{2}{c|}{$\begin{array}{c}\text { Yazılı Sınavı İlk Hakkında } \\
\text { Geçemeyenlerin Sayısı \% }\end{array}$} \\
\hline Kadın & 9 & 100.0 & - & - \\
\hline Erkek & 14 & 66.6 & 7 & 23.3 \\
\hline Toplam & 23 & 76.7 & 7 & \\
\hline
\end{tabular}

Görüldüğü üzere sürücü adaylarının çoğunluğu (\%76.7) yazılı sınavı ilk haklarında geçmişlerdir. Ancak, kadın ve erkek sürücü adaylarının yazılı sınav başarıları birbirlerinden farklıdır: Kadın sürücü adaylarının tamamı yazılı sınavda ilk haklarında başarılı olurken, erkek sürücü adaylarının \%33,3'ü başarısız olmuştur.

Görüşmelerde adaylara sürücülüğü öğrenmek için Motorlu Taşıt Sürücü Kursu'ndaki eğitim dışında başka bir ders, kurs ya da özel çalışmaları olup olmadığ 1 sorulmuştur. Görüşülen bireylerin cevaplarının dağılımı Tablo 3'te gösterilmiştir. 
Tablo 3. Görüşülen Sürücü Adaylarının Kurs Dışında Sürücülüğü Öğrenmeye Yönelik Çalışma Yapıp Yapmamalarına Göre Dağılımı (n:30)

\begin{tabular}{|c|c|c|c|c|c|c|}
\hline \multirow{2}{*}{ MTSK Dışında Çalışma } & \multicolumn{2}{|c|}{ Erkek } & \multicolumn{3}{c|}{ Kadın } & \multicolumn{2}{c|}{ Toplam } \\
& Sayı Sayı & $\%$ & \multicolumn{2}{c|}{ Sayı } & \multicolumn{1}{c|}{$\%$} \\
\hline Yaptı & 6 & 28.6 & 2 & 22.2 & 8 & 26.7 \\
\hline Yapmadı & 15 & 71.4 & 7 & 77.7 & 22 & 73.3 \\
\hline Toplam & 21 & 100.0 & 9 & 100.0 & 30 & 100.0 \\
\hline
\end{tabular}

Görüldüğü üzere sürücü adaylarının yaklaşık 3/4'ü sürücülüğü öğrenmeye yönelik kursla eşzamanlı kurs dışı çalışmaları olmadığını belirtmişlerdir. Bu durumu şu sözlerle ifade etmişlerdir:

Kardeşimden daha önce öğrenmiştim (SA 14).

Eşimle çalışarak kursa gitmeden önce öğrenmiştim (SA 28) .

Babamla zaman zaman çalıştı̆̆ım için kurstan önce araç kullanmayı biliyordum (SA 24).

Kuzenim öğretmişti. Zaten araç kullanmayı biliyordum (SA 10).

Köyde traktör sürerek öğrenmiştim (SA 9).

Sürücülüğü öğrenmeye yönelik kurs dışı çalışmaları olmadığını belirten 22 adaydan 19'u kursa başlamadan önce araç kullanmayı bildiklerini ifade etmişlerdir.

Ancak sürücü adaylarının 1/4'ünden biraz fazlası sürücülüğü öğrenmek için kurs dışında da çalıştıklarını ifade etmişlerdir. Kurs dışında da sürücülüğü öğrenmeye yönelik çalışması olan adaylar bu durumu şu sözlerle ifade etmiş̧lerdir:

Sadece direksiyon dersi için amcam ve babamla çalıştım (SA 27).

Kendi aracımla boş alanlarda çalıştım (SA 26).

1,5 yıldır ağabeyimle çalışıyordum (SA 8).

Babamla çalıştım (SA 12).

Çizelge 4'te görüldüğü üzere görüşülen adayların çoğunluğu (\%76.6) sürücülüğü kurs dışında öğrendiklerini ifade etmişlerdir. Aslında sürücü adaylarının büyük çoğunluğunun, kursa başlamadan önce veya kursla eşzamanlı olarak, sürücülügü öğrenmek için kurs dışında informal öğrenme çalışmaları yaptıkları anlaşılmaktadır.

Adaylardan yalnızca 1 kişi kayıtlı olduğu motorlu taşıt sürücü kursundan ek ders aldığını belirtmiştir.

Görüşülen sürücü adaylarının direksiyon eğitiminden önce motorlu taşıt kullanmayı bilip bilmedikleri ve kullanıp kullanmadıkları kendilerine sorulmuş ve alınan cevapların dağılımı Tablo 4'te gösterilmiştir.

Tablo 4. Sürücü Adaylarının Kurstaki Eğitiminden Önce Motorlu Taşıt Kullanmayı Bilip Bilmediklerine, Kullanıp Kullanmadıklarına Göre Dağılımı (n:30)

\begin{tabular}{|c|c|c|c|c|c|c|}
\hline \multirow{2}{*}{$\begin{array}{c}\text { Kurstan Önce Araç } \\
\text { Kullanmayı Biliyor mu? }\end{array}$} & \multicolumn{2}{|c|}{ Erkek } & \multicolumn{2}{c|}{ Kadın } & \multicolumn{2}{c|}{ Toplam } \\
Sayı & \% & \multicolumn{2}{|c|}{ Sayı } & \% & \multicolumn{2}{c|}{ Sayı } \\
\hline Evet & 18 & 85.7 & 5 & 55.5 & 23 & 76.6 \\
\hline Hayır & 3 & 14.3 & 4 & 44.5 & 7 & 23.3 \\
\hline Toplam & 21 & 100.0 & 9 & 100.0 & 30 & 100.0 \\
\hline
\end{tabular}


Görüldüğü üzere sürücü adaylarının 3/4'ünden fazlasının (\%76.6) motorlu taşıt sürücü kursunda eğitime başlamadan önce araç kullanmayı bildikleri, yalnızca yaklaşık 1/4'ünün (\%23.4) araç kullanmayı bilmeden kursa katıldığı anlaşılmaktadır.

Motorlu taşıt sürücü kursunda eğitime başlamadan önce araç kullanmayı bildiklerini belirten adaylardan 13'ü araba kullanmayı babasından, 6'sı kardeşinden, 4'ü ise bir akrabasından öğrendiğini beyan etmiştir. Kurstan önce araç kullanmayı bildiğini beyan eden erkek adayların görüşülen erkek adayların büyük çoğunluğunu (\%85.7) oluşturduğu görülmektedir. Kadın adaylarda ise kurstan önce araç kullanmayı bilen adayların oranı (\%55.5) ile bilmeyen adayların oranının (\%44.5) birbirine çok yakın olduğu görülmektedir.

Görüşülen adaylara sürücü belgelerini aldıkları gün kendilerini her türlü yol ve hava şartlarında araç kullanmaya hazır hissedip hissetmedikleri sorusu yöneltilmiştir. Görüşülen bireylerin cevaplarının dağılımı Çizelge 5'te gösterilmiştir.

Tablo 5. Görüşülen Sürücü Adaylarının Sürücü Belgelerini Aldıkları Gün Kendilerini Her Koşulda Araç Kullanmaya Hazır Hissedip Hissetmemelerine Göre Dağılımı (n:30)

\begin{tabular}{|c|c|c|c|c|c|c|}
\hline \multirow{2}{*}{$\begin{array}{c}\text { Araç Kullanmaya Hazır Hissediyor } \\
\text { musun? }\end{array}$} & \multicolumn{2}{|c|}{ Erkek } & \multicolumn{2}{c|}{ Kadın } & \multicolumn{3}{c|}{ Toplam } \\
Sayı & Sayı & \% & \multicolumn{2}{|c|}{ Sayı } \\
\hline Evet. Hazııım. & 12 & 57.1 & 1 & 11.1 & 13 & 43.3 \\
\hline Hayır. Hazır değilim. & 8 & 38.0 & 8 & 88.9 & 16 & 53.3 \\
\hline Emin değilim & 1 & 4.8 & - & 0.0 & 1 & 3.3 \\
\hline Toplam & 21 & 100.0 & 9 & 100.0 & 30 & 100.0 \\
\hline
\end{tabular}

Görüldüğü üzere sürücü adaylarının yaklaşık yarısı (\%43.3) kendisini araç kullanmaya hazır hissetmekte; yarısından biraz fazlası ise (\%53.3) hazır hissetmemektedir.

Kendilerini her türlü yol ve hava şartlarında araç kullanmaya hazır hissettiklerini ifade eden 11 aday görüşmelerde kursa başlamadan önce araç kullanmayı bildiklerini ifade etmişlerdir. Kendini hazır hisseden bir aday durumu "babamla çok fazla çalışma yaptığım için kendimi hazır hissediyorum" (SA 11) sözleriyle ifade etmiştir. Tablodan anlaşıldığı üzere sürücü belgesini aldığı gün hazır olanlar aslında kursa başlamadan önce araç kullanmayı bilenlerdir.

\subsection{Yorum ve Tartışma}

Görüldüğü üzere sürücü adaylarının büyük çoğunluğunun (\%76.6) Motorlu Taşıt Sürücüleri Kursu'na başlamadan önce araç kullanmayı bildikleri, yalnızca yaklaşık 1/4'ünün (\%23.4) araç kullanmayı bilmeden kursa katıldığı anlaşılmaktadır. Kursa araç kullanmayı bilerek katılanlar, araç kullanmayı baba, ağabey, amca gibi yakın akrabalarından öğrendiklerini ifade etmişlerdir.

Birer yetişkin olan sürücü adaylarının, non formal eğitim olarak tanımlayabileceğimiz Motorlu Taşıt Sürücüleri Kursu'na katılmadan önce plansız, tasarlanmamış ve yapılandırılmamış şekilde sürücülüğ̈̈ öğrenme çalışmalarının yaygınlığı informal öğrenmelerin önemini ve baskın rolünü ortaya koymaktadır. Tursting ve Barton $(2011,60)$, informal öğrenme konusundaki çalışmaların, öğrenmenin derslik ve öğrenme ortamları dışında da oluşabileceğinin farkına varılmasının gerekliliğine işaret eder. Buna göre derslik ile diğer öğrenmeler arasında ilişki kurulmalıdır.

Candy (1991), tarafından formel kurumsal yapıların dışında öğrenmenin bağımsız takibi olarak kendini yetiştirme (autodidaxy) etkinliği olarak tanımlanan öz-yönelimli öğrenme 
(Tursting, \& Barton, 2011, 53-54), ne öğrenileceğine, nasıl öğrenileceğine öğrenenin karar verdiği bir süreçtir (Miser, 2013, 155). Görüşme yapılan sürücü adayları öz-yönelimli birer öğrenen olarak sorumluluk alıp sürücülüğü öğrenme konusunda yürüttükleri çalışmalar sonucu gerçekleşen öğrenmeleri kurstaki çalışmalarına eklemlemiştir.

\section{Sonuçlar ve Öneriler}

Sürücü adaylarının büyük çoğunluğunun (\%76.6) Motorlu Taşıt Sürücüleri Kursu'na başlamadan önce sürücülügü öğrenmek için informal çalışmalar yaptıkları için araç kullanmayı bildikleri, yalnızca yaklaşık 1/4'ünün (\%23.4) araç kullanmayı bilmeden kursa katıldığı; bir kısmının da araç kullanmayı öğrenmek için kursla eş zamanlı olarak informal biçimde öğrenmeyi de sürdürdükleri anlaşılmaktadır.

Kursa araç kullanmayı bilerek katılanlar, araç kullanmayı baba, ağabey, amca gibi yakın akrabalarından informal yolla öğrenmektedirler.

MEB tarafından yapılan sınavı başarıyla geçen adayların yarıya yakını (\%43.3) her türlü hava ve yol koşulunda araç kullanmaya kendini hazır hissetmekte iken yarıdan fazlası kendini hazır hissetmemektedir. Bu durum sürücülüğün hem non formal hem de informal olarak trafik açısından düşük yoğunluklu yerlerde öğrenilmeye çalışılmasının bir sonucu olarak değerlendirilmektedir.

Sürücü eğitimi, sınav sistemi ve belgelendirme sistemi üzerindeki katı bürokratik yapı değiştirilerek hizmetlerin sürücü adaylarının kolay erişebileceği, her an yararlanabileceği şekilde sunulduğu daha kullanışlı bir hale dönüştürülmelidir.

Sürücülere yönelik eğitimin amacı yetkin sürücülerin yetiştirilmesi olduğundan; teorik eğitim ve direksiyon eğitimi belirli ders saatleri ile sınırlandırılmamalıdır. Eğitim bir süreçtir ve bu sürecin beklenen şekilde sonuçlanmasını sağlayan etkenlerin başında öğrenenin bireysel özellikleri gelmektedir. Farklı bireysel özelliklere sahip sürücü adaylarının öğrenme hızları ve seviyeleri de farklılıklar göstereceğinden teorik sınava ve direksiyon sınavına hazırlıkta sürücü adayları aynı içeriği aynı sürede öğrenemeyecektir. Yetişkin birer birey olan sürücü adayları teorik sınava kendi yaşamlarına uygun zamanlarda, özel kursların yardımıyla ya da kişisel çalışmalarıyla hazırlanabilmeli ve teorik sınava girmeye kendilerini hazır hissettiklerinde kendi başvurularıyla sınava girmelidir.

Sürücü adaylarına teorik sınava hazırlık aşamasında içeriği yetkili özerk otorite tarafindan uygun görülen eğitim kaynaklarına kolay erişebilme imkanı sunulmalıdır. Direksiyon eğitimi yine sürücü adaylarının kendi yaşamlarına uygun zamanlarda yürütülen mecburi ders uygulaması ile yetkin sürücülüğe erişinceye kadar devam eden çalışmaları içeren iki bölümden oluşmalıdır. Mecburi ders uygulaması yetkili özel sürücü kurslarında temel sürücülük becerilerini içeren standart bir uygulama olarak sunulmalıdır. Bu eğitimi takiben sürücü adayı her türlü hava ve yol şartında araç kullanma becerisine sahip olana kadar kendi talebi doğrultusunda yetkili bir eğitimci ya da belirli kıstaslara sahip bir gözetmen nezaretinde araç kullanmayı öğrenmeye devam etmelidir.

Sürücü adayları teorik sınavı başarmalarının ardından yapacakları çalışmalar (informal veya non formal) sonucu kendilerini direksiyon sınavına girmeye hazır hissettiklerinde kendi başvurularıyla sınava girmelidir. Adaylar yetkili özel sürücü kurslarında alacakları eğitim sonucu direksiyon sınavına başvurabilecekleri gibi yaşam boyu öğrenme çerçevesinde teorik sınavı müteakip kendilerini sınava hazır hissettiklerinde de direksiyon sınavına girebilmelidir. 


\section{KAYNAKÇA}

Aziz, A. (1990). Araştırma Yöntemleri-Teknikleri ve Illetişim. Ankara: A.Ü. Siyasal Bilgiler Fakültesi ve Basın-Yayın Yüksekokulu Basımevi.

Balcı, A. (2006). Sosyal Bilimlerde Araştırma. Ankara: Pegem Yayıncılık.

Blacker, H. (2005). "Learning From Experience”. Eds. Richardson, L., D., \& Wolfe, M. Principles and Practice of Informal Education, 85-91. London-New York: Routledge Falmer.

Böke, K. (Edt.). Özdoğan, A., Sevinç, B., Gürer, C., Büker, H., Demir, H. (2009). Sosyal Bilimlerde Araştırma Yöntemleri (1. Basım). Ankara: Alfa Yayınları.

Cross, J. (2007). Informal Learning (Rediscovering The Natural Pathways that Insprire Innovation and Performance). San Francisco: Wiley Imprint.

Davis, A., \& Quimby, A. (2003). DFID - Promoting Road Safety in Developing Countries Through Community Education Programme. Unpublished Project Report. Transport Research Laboratory January2003-http://www.transportlinks.org/transport_links/filearea/documentstore/302_Literature \%20Review\%20-\%20Draft.pdf-adresinden 17.12.2010'da alınmıştır.

Drago-Severson, E. (2004). Becoming Adult Learners. New York \& London: Teachers College.

DTMR. (2013). http://www.tmr.qld.gov.au/Safety/Driver-guide/Driver-education.asp-adresinden 10 Aralık 2013'de alınmıştır.

Erdoğan, İ. (2003). Pozitivist Metodoloji. Ankara: ERK.

Hillier, Y. (2005). Reflective Teaching in Further and Adult Education. Continuum, London.

Karasar, N. (2011). Bilimsel Araştırma Yöntemi. Ankara: Nobel Yayıncılık.

Knowles, M. S. (1996). Yetişkin Öğrenenler. Çev.: Serap Ayhan. Ankara: Ankara Üniversitesi Basımevi.

Knowles, M., S., Holton, E., F., \& Swanson, R., A. (2011). The Adult Learner. Burlington: Elsevier.

Merriam, S., B., \& Kim, Y., S. (2008). "Non-Western Perspectives on Learning and Knowing. Fenwick, Tara. (2008). Workplace Learning: Emerging Trends and New Perspectives”. Ed. Merriam, S.. B. Third Update on Adult Learning Theory. San Francisco: Jossey-Bass.

Merriam, S. B. (2011). “Adult Learning”. Ed. Rubenson, Kjell. Adult Learning and Education. Kidlington: Elsevier.

Miser, R. (1999). Halk Ĕgitimi ve Toplum Kalkınması. Ankara: MEB-Türk Tarih Kurumu Basımevi.

Miser, R. (2013). Yaşamboyu Öğrenme Kavram ve Bağlam. Ankara: EBF-MD Yayını.

Rogers, J. (2007). Adult Learning, Fifth Edition. Berkshire:. McGraw-Hill.

Tusting, K., \& Barton, D. (2011). Öğrenme Kuramlart ve Yetişkin Öğrenme Modelleri. Çev.: Ahmet, Yıldız, \& Aylin, Demirli. Ankara, Dipnot Yayınları.

Varış, F. (Edt.), Gürkan, T., Gözütok, D., Bektaş, S., Babadoğan, C., \& Gürbüztürk, O. (1998). Eğitim Bilimine Giriş. İstanbul: Alkım Yayınları.

Venter. (2010). "Traffic Safety Education and Campaigns". South African Transport Conference Organised by: Conference Planners 'Action in Transport for the New Millennium' South Africa, (1720 July 2000) http://repository.up.ac.za/bitstream/handle/2263/8333/48\%20Venter.pdf?sequence $=1$ adresinden 13.12.2010'da alınmıştır.

Werquin, P. (2010). Recognising Non-Formal and Informal Learning (Outcomes, Policies and Practices). OECD.

Yıldırım, A., \& Şimşek, H. (2003). Sosyal Bilimlerde Nitel Araştırma Yöntemleri. Ankara: Seçkin Yayınları.

Young, K., \& Regan, M. (2007). "Driver distraction: A Review of the Literatüre”. Eds. Faulks, I., J., Regan, M., Stevenson, M., Brown, J., Porter, A., \& Irwin, J., D. Distracted Driving, 379-405. Sydney: Australasian College of Road Safety. http://www.erskinemcmahon.com/files/cell.phone.driving. distraction.article.10.pdf-adresinden 12 Aralık 2013'de alınmıştır.

2918 sayılı Karayolları Trafik Kanunu. 18.10.1983 - 18195 sayılı R.G. 
